\title{
UPAYA PENINGKATAN KUALITAS PEMBELAJARAN MATA KULIAH LOGIKA DAN HIMPUNAN MELALUI LESSON STUDY BERBASIS TEMAN SEJAWAT
}

\author{
Ahmadi, M. Shaefur Rokhman, Paridjo, \\ Universitas Pancasakti Tegal \\ email korespondensi: ahmadi_ak@yahoo.com
}

\begin{abstract}
Abstrak-Tujuan dari penelitian ini adalah untuk mendeskripsikan bagaimana peningkatkan proses pembelajaran dalam memahami mata kuliah Logika dan Himpunan. Dari penelitian yang telah dilakukan, dapat disimpulkan beberapa hal diantaranya : (1) proses pembelajaran pada lesson study II sudah lebih baik setelah dilakukan perbaikan terhadap masalah pada lesson study I. Pada lesson study II, suasana kelas dalam proses pembelajaran sangat kondusif karena perhatian mahasiswa sudah terfokus pada kegiatan pembelajaran, mahasiswa sudah memahami materi pelajaran dan mahasiswa sudah mampu menerapkan metode pembelajaran tutor sebaya (Reciprocal teaching). mahasiswa lebih antusias dan lebih termotivasi dalam pembelajaran dengan menggunakan metode tutor sebaya (Reciprocal teaching) karena mahasiswa tidak hanya sekedar tahu materi yang dipelajarai tetapi juga lebih memahami dan mempertanggungjawabkan hasil belajarnya. Pembelajaran dengan menggunakan metode tutor sebaya juga mengajarkan akan pentingnya kerjasama dan saling berbagi baik itu memberi atau menerima demi tercapainya tujuan yang diinginkan, (2) adanya peningkatan hasil belajar antara Lesson Study I dan Lesson Study II. Peningkatan itu terlihat dari perubahan nilai rata-rata dari lesson study I ke lesson study II sebesar 69,2 \%. Pada lesson study I, nilai rata-rata yang diperoleh mahasiswa sebesar 84,6 pada lesson study II, hasil yang dicapai mahasiswa sebesar $15,4 \%$
\end{abstract}

Kata kunci: Logika dan Himpunan, Lesson Study, Tutor Sebaya 


\section{PENDAHULUAN}

Pengalaman peneliti, dalam perkuliahan Logika dan Himpunan ada kecenderungan mahasiswa kurang aktif atau bersifat pasif sehingga ruh dari sebuah proses pembelajaran seakan - akan tidak ada. Mahasiswa dalam menyelesaikan permasalahan cenderung mengikuti langkah-langkah penyelesaian yang sudah digariskan oleh dosen.

Salah satu upaya untuk meningkatkan kualitas pembelajaran saat ini adalah melalui implementasi Lesson Study. Lesson Study merupakan salah satu upaya pembinaan untuk meningkatkan proses pembelajaran yang dilakukan oleh sekelompok guru/dosen/dosen secara kolaboratif dan berkesinambungan, dalam merencanakan, melaksanakan, mengobservasi dan melaporkan hasil pembelajaran. Lesson Study merupakan kegiatan yang dapat mendorong terbentuknya sebuah komunitas belajar (learning society) yang secara konsisten dan sistematis melakukan perbaikan diri, baik pada tataran individual maupun manajerial. Slamet Mulyana (2007) memberikan rumusan tentang Lesson Study sebagai salah satu model pembinaan profesi pendidik melalui pengkajian pembelajaran secara kolaboratif dan berkelanjutan berlandaskan pada prinsip-psrinsip kolegalitas dan mutual learning untuk membangun komunitas belajar.

Selain Lesson Study, salah satu cara yang bisa ditempuh adalah menerapkan metode pembelajaran yang melibatkan keaktifan mahasiswa. Selain guru/dosen sebagai salah satu sumber belajar, ternyata mahasiswa juga memiliki potensi yang dapat dimanfaatkan dalam proses pembelajaran. Sehubungan dengan hal ini, Suherman, dkk. (2001 : 232) mengatakan, "Sumber belajar selain guru/dosen, yaitu teman sebaya yang lebih pandai memberikan bantuan belajar kepada teman-teman sekelasnya di sekolah yang disebut metode tutor sebaya". Metode tutor sebaya dilakukan atas dasar bahwa ada sekelompok mahasiswa yang lebih mudah bertanya, lebih terbuka dengan teman sendiri dibandingkan dengan guru/dosennya. Disiplin diri yang diberikan mahasiswa dengan didasari oleh motivasi yang positif dari internal dan eksternal mahasiswa baik yang prestasinya tinggi (si tutor) maupun mahasiswa yang yang prestasinya rendah (si mentor) demi terciptanya suatu kondisi yang tepat bagi mahasiswa untuk secara maksimal menerima bahan ajaran, sehingga tugas yang diberikan seorang guru/dosen tidak dianggap sebagai suatu keterpaksaan atau beban oleh mahasiswa melainkansebagai suatu kebutuhan yang harus dipenuhi.

Metode tutor sebaya atau biasa juga di sebut dengan reciprocal teaching adalah pendekatan konstruktif yang didasarkan pada prinsip-prinsip penurunan pertanyaan, mengajar dengan keterampilan metakognitif (merangkum, meringkas, mengklarifikasi, dan memprediksi) melalui pengajaran dan pemodelan guru/dosen untuk meningkatkan penampilan mahasiswa terhadap materi pelajaran. Dalam konteks ini, mahasiswa perlu mengerti makna belajar, manfaat belajar, status pembelajaran, dan proses pencapaiaannya. Mahasiswa sadar bahwa hal yang dipelajarinya berguna bagi kehidupannya nanti. Dengan begitu, mereka mempromosikan diri sendiri yang memerlukan sesuatu bekal untuk hidupnya nanti.Mereka mempelajari hal yang bermanfaat bagi dirinya dan berupaya menggapainya. Dalam upaya itu, mereka memerlukan guru/dosen sebagai pengarah dan pembimbing. 
Berdasarkan uraian di atas dapat dirumuskan suatu permasalahan sebagai berikut.

a. Bagaimanakah peningkatkan proses pembelajaran dalam memahami mata kuliah Logika dan Himpunan

b. Bagaimanakah peningkatkan hasil pembelajaran memahami mata kuliah Logika dan Himpunan

Tujuan dari penelitian ini berdasarkan rumusan masalah di atas adalah sebagai berikut:

a. Untuk mendeskripsikan bagaimana peningkatkan proses pembelajaran dalam memahami mata kuliah Logika dan Himpunan.

b. Untuk mendeskripsikan bagaimana peningkatkan hasil pembelajaran memahami mata kuliah Logika dan Himpunan.

\section{KAJIAN LITERATUR DAN PEGEMBANGAN HIPOTESIS (JIKA ADA)}

Lesson Study merupakan salah satu upaya pembinaan untuk meningkatkan proses pembelajaran yang dilakukan oleh sekelompok guru secara kolaboratif dan berkesinambungan, dalam merencanakan, melaksanakan, mengobservasi dan melaporkan hasil pembelajaran. Lesson Study merupakan kegiatan yang dapat mendorong terbentuknya sebuah komunitas belajar (learning society) yang secara konsisten dan sistematis melakukan perbaikan diri, baik pada tataran individual maupun manajerial. Slamet Mulyana (2007) memberikan rumusan tentang Lesson Study sebagai salah satu model pembinaan profesi pendidik melalui pengkajian pembelajaran secara kolaboratif dan berkelanjutan berlandaskan pada prinsip-psrinsip kolegalitas dan mutual learning untuk membangun komunitas belajar.
Lewis (2002) mengungkapkan bahwa Lesson Study memberikan kesempatan bagi guru untuk:

a. memikirkan baik-baik tentang tujuan pelajaran, materi, dan topik tertentu.

b. Memikirkan secara mendalam tentang tujuan jangka panjang bagi siswa. Kesenjangan apa yang ada diantara kondisi siswa dan tujuanyang akan dicapai.

c. Mempelajari dan mengembangkan pelajaran terbaik yang terjangkau.

d. Memperdalam pengetahuan materi mereka sendiri, dengan mempertimbangkan pertanyaan seperti: pengetahuan dan pemahaman apa yang penting ?; bagaimana cara mengembangkan ?; kesenjangan apa yang ada dalam pemahaman siswa dan pengetahuan?

e. Secara kolaboratif merencanakan pelajaran.

f. Mengantisipasi pikiran siswa.

g. Berhati-hati dalam mempelajari cara belajar dan perilaku siswa.

Membangun strategi pembelajaran yang kuat - misalnya, mengembangkan strategi bertanya yang merangsang minat dan belajar siswa.

Slavin (1994: 233) mengemukakan bahwa reciprocal teaching adalah pendekatan konstruktif yang didasarkan pada prinsip-prinsip penurunan pertanyaan, mengajar dengan keterampilan metakognitif (meranmgkum, meringkas, mengklarifikasi, dan memprediksi) melalui pengajaran dan pemodelan guru/dosen untuk meningkatkan penampilan mahasiswa terhadap materi kuliah.

Menurut Trianto (2002:173-174) metode tutor sebaya merupakan satu pendekatan terhadap pengajaran mahasiswa. Pengajaran tutor sebaya adalah pendekatan konstruktivis yang 
berdasar pada prinsip-prinsip membuatan/pengajuan pertanyaan, dimana keterampilan-keterampilan metakognitif diajarkan melalui pengajaran langsung dan pemodelan oleh guru/dosen untuk memperbaiki kinerja membaca mahasiswa yang membaca pemahamannya rendah Selanjutnya guru/dosen menunjuk seorang mahasiswa untuk menggantikan perannya sebagai guru/dosen bertindak sebgai pemimpin diskusi dalam kelompok tersebut, dan guru/dosen beralih peran dalam kelompok tersebut sebagai motivator, mediator, pelatih, dan memberi dukungan, umpan balik, serta semanmgat bagi mahasiswa. Secara bertahap beransur-ansur guru/dosen mengalihkan tanggung jawab pengajaran yang lebih banyak kepada mahasiswa dalam kelompok, serta membantu memeonitor berpikir dan starategi yang digunakan.

Tahap - tahap dalam kegiatan Tutor Sebaya :

a. Tahap Perencanaan

Tahap perencanaan terdiri atas empat yaitu:

1) Memikirkan pertanyaanpertanyaan penting yang mungkin muncul tentang hal apa yang dibaca dan untuk menyakinkan bahwa anda dapat menjawab pentanyaanpertanyaan itu;

2) Merangkum informasi penting dari bacaan-bacaan yang telah dibaca;

3) Memprediksi yang dibahas oleh pengarang pada pokok bahasan berikutnya;

4) Memberi tanda hal yang tidak jelas dengan paragraf yang telah dibaca.

b. Tahap Pelaksanaan dan Prosodur Harian

Slavin (1994:234) mengumukakan enam tahap metodepelaksanaan tutor sebaya (reciprocal teaching), yaitu:

1) Dalam pelaksanaan pembelajaran, guru/dosen tidak dapat hanya memberi kemudahan untuk proses belajar mahasiswa, tetapi guru/dosen memberi kesempatan kepada mahasiswa untuk menemukan atau menerapkan ide-ide dalam pelaksanaan pembelajaran, guru/dosen tidak dapat hanya memberi kemudahan untuk proses belajar mahasiswa, tetapi guru/dosen memberi kesempat mahasiswa untuk menemukan atau menerapakan ide-ide mereka sendiri. Prinsip ini tampak pada kegiatan (penjelasan), merangkum (meringkas) dengan berbagi metode masing-masing mahasiswa untuk menemukan ide pokok seperti pelakukan metode underlining, notelaking, dan sebagainya;

2) Guru/dosen memberikan mahasiswa anak tangga yang membawa mahasiswa kepada pemahaman yang lebih tinggi. Prinsip ini tampak pada kegiatan mahasiswa mengerjakan (lembar kerja mahasiswa) yang dapat mengantarkan mahasiswa untuk memahami komsek yang abstrak menjadi konsep yang nyata melalui strategi analog, perolehan kesempatan bersama melalui kegiatan klasifikasi konsep;

3) Pembelajaran hendaknya memusatkan pada berpikir atau proses mental mahasiswa tidak sekedar pada hasilnya, prinsip ini tujukan pada kegiatan pemahaman bacaan untuk menentukan konsep kunci; 
4) Memperhatikan peran aktif dan inisiatif mahasiswa. Prinsip ini tampak terlihat pada aktivitas mahasiswa secara fisik dalam melakukan kegitan merangkum, menyusun pertanyaan, mengklasifikasi, dan melakukan kegiatan pembelajaran

5) Memaklumi adanya perbedaan individual dalam kemajuan dan perkembangan. Prinsip ini tampak pada pembentukan kelompok-kelompok dalam melakukan pembelajaran;

6) Scaffolding. Prinsip ini tampak pada kegiatan pemodelan guru/dosen pada tahap awal melakukan pembelajaran (bimbingan bagaimana membuat pertanyaan, bagaimana merangkum, dan bagaimana menjadi mahasiswaguru/dosen), kemudian pada tahap-tahap berikutnya mahasiswa sudah dilepas.

c. Tahap Evaluasi

Tahap evaluasi ini terdiri enam langkah berikut ini:

1) Disediakan materi kuliah yang dapat diselesaikan dalam satu kali pertemuan;

2) Dijelaskan bahwa pada segmen pertama ada salah seorang mahasiswa berperan sebagai guru/dosen

3) Mahasiswa diberikan tugas untuk membaca dan memahami materi

4) Mahasiswa telah membaca, dilanjudkan dengan membuat pertanyaan;

5) Mahasiswa dilatih berperan sebagai seorang guru/dosen dalam proses belajar mengajar sesuai dengan konsep reciprocal teaching, mahasiswa lain diminta berpartisipasi dalam dialog dan selalu diinginkan bahwa pada segmen ini semuanya berperan sebagai guru/dosen yang sebelumnya, menuntun dialog meyakinkan mahasiswa dengan banyak memberi umpan balik dan pujian;

6) Pada pertemuan berikutnya lebih banyak kegiatan berdialog sehingga pada saat mahasiswa berperan sebagai guru/dosen sudah mulai berinisiatif pada kegiatan mereka sendiri (slavin, 1994:235-236)

\section{METODE PENELITIAN}

Penelitian ini digolongkan ke dalam jenis penelitian tindakan kelas (classroom action research). Penelitian tindakan kelas ini pada hakikatnya merupakan penelitian yang sifatnya kualitatif meskipun di dalamnya terdapat data-data kuantitatif.

Data kualitatif diperoleh dari lembar observasi atau lembar catatan lapangan terhadap perilaku guru dan respon siswa dalam setiap pelaksanaan tindakan (proses pembelajaran) pada lesson study I dan II, dan data kuantitatif diperoleh dari tes akhir setiap tindakan.

Penelitian tindakan kelas (PTK) berfokus pada kelas atau pada proses belajar mengajar yang terjadi di kelas, bukan pada input kelas (silabus, materi, dan lain-lain) ataupun output hasil belajar. Menurut Arikunto, dkk (2011: 58-61) Penelitian tindakan kelas (PTK) adalah penelitian tindakan yang dilakukan di kelas dengan tujuan memperbaiki atau meningkatkan mutu praktik pembelajaran, meningkatkan profesionalisme, dan menumbuhkan budaya akademik.

Observer pada penelitian ini adalah dosen dan mahasiswa UPS Tegal yang telah tergabung dalam komunitas Lesson Study. Subjek dalam penelitian ini adalah mahasiswa semester I pendidikan matematika UPS Tegal. 
Dalam penelitian ini mekanisme pelaksanaannya mengikuti kegiatan Lesson Study. Adapun fase dalam kegiatan Lesson Study adalah sebagai berikut :

Fase I : Plan

Dalam kegiatan Plan ini meliputi :

a. Membuat jadwal pertemuan

b. Menentukan tempat pertemuan

c. Membuat undangan kepada anggota tim Lesson Study

d. Menyiapkan alat-alat yang dibutuhkan, seperti pensil, pulpen, kertas, blocknote, dan lain-lain

e. Menentukan tujuan untuk dicapai oleh tim Lesson Study

Fase II : Do

Pada langkah ini yang dilakukan adalah sebagai berikut :

a. Salah satu anggota tim memberikan pelajaran (mengajar), kemudian anggota tim yang lain melakukan observasi pada pelajaran tersebut. Hasil observasi akan memberikan catatan yang detil dan mengumpulkan bukti tanpa membuat penilaian sebelum melaksanakan diskusi.

b. Semua anggota tim, kecuali yang sedang mengajar, adalah observer. Para observer memberikan berbagai pandangan baru dan dapat mengumpulkan bukti dari pemikiran dan pemahaman siswa.

c. Sebelum melaksanakan observasi, tim menentukan data apa yang akan dikumpulkan dan menugaskan bagi setiap anggota untuk menjadi pengamat dalam pelajaran.

Fase III : See

Pada tahap See dalam Lesson Study membutuhkan fasilitator yang mampu menarik semua anggota tim untuk terlibat secara produktif. Fasilitator memandu proses diskusi tanpa mengkritik anggota sehingga merusak atau melemahkan tim. Fasilitator tim haruslah: a) cerdas, luas pengetahuan, dan bijaksana, 2) mampu memodelkan pendekatan analitis dalam diskusi, 3) mengatur diskusi dengan baik.

Langkah-langkah dalam kegiatan See, yaitu sebagai berikut:

a. Guru yang mengajar memberikan komentar terhadap pelajaran yang telah dilaksanakan. Setiap anggota tim harus mendengarkan komentar sampai dengan selesai.

b. Setiap anggota tim memberikan komentar terhadap pelajaran yang telah dilaksanakan.

c. Diskusi dilaksanakan secara terbuka.

d. Fasilitator memberikan komentar dan merangkum hasil diskusi.

Diskusi dilakukan pada bukti atau petunjuk tentang pikiran dan pembelajaran siswa. Diskusi difokuskan pada tim pelajaran, bukan pada guru. Para observer berbagai bukti yang telah dikumpulkan dan mendiskusikan implikasi untuk pelajaran selanjutnya.

Instrumen yang digunakan dalam penelitian ini adalah lembar observasi, dan soal tes

a. Lembar observasi

Lembar observasi digunakan untuk mendapatkan informasi mengenai proses pembelajaran mahasiswa dengan menggunakan metode tutor sebaya.

b. Tes

Tes digunakan untuk menguji kemampuan mahasiswa di tiap lesson study

Analisis data kualitatif dilakukan dengan mendeskripsikan aktivitas guru dan siswa dengan mengacu pada hasil observasi terhadap guru dan siswa dalam proses pembelajaran. Data yang diperoleh dari lesson study I dan lesson study II dibandingkan untuk mengetahui peningkatan proses pembelajaran.

Analisis data secara kuantitatif dilakukan dengan menghitung skor 
perolehan siswa berdasarkan hasil pekerjaannya pada saat tes di setiap pertemuan. Pengelolaan data kuantitatif menggunakan rumus: Nilai $=\frac{\text { skor yang diperoleh siswa }}{\text { skor maksimal }} \times 100$

\section{HASIL DAN PEMBAHASAN}

a. Pelaksanaan Lesson Study I

1) Tahap Plan

Pada tahap ini, guru/dosen secara bersama-sama melakukan analisis silabus untuk membuat lesson design. Kegiatan lesson design ini dilakukan untuk merancang kegiatan yang akan dilaksanakan pada saat proses pembelajaran.

2) Tahap Do

Pada kegiatan open class ini dihadiri oleh teman dosen dan mahasiswa semester akhir sebagai pengamat. Para pengamat mengamati pengelolaan kelas untuk uji keterbacaan bahan pembelajaran berupa modul hasil pengembangan dari belakang kelas. Berdasarkan hasil pengamatan menunjukkan bahwa mahasiswa tampak antusias dan berperan aktif dalam setiap diskusi antar kelompok yang dipandu oleh teman sebayanya. Pada kegiatan mahasiswa berdiskusi dalam kelompok belum menunjukkan hasil yang baik, hal ini dibuktikan dengan adanya $14 \quad(56 \%)$ mahasiswa yang aktif, 11 mahasiswa (44\%) yang tidak aktif.

Pada kegiatan mengumpulkan hasil diskusinya dan menunjuk perwakilan untuk memaparkan hasil diskusi di depan temantemannya untuk mendapatkan tanggapan diperoleh data sebayak $10(40 \%)$ mahasiswa yang aktif, 15 mahasiswa $(60 \%)$ yang tidak aktif. Pada kegiatan menyimpulkan hasil pembelajaran terdapat 12 mahasiswa yang aktif (48\%), dan 10 mahasiswa (52\%) yang tidak aktif. Menurut pengamatan peneliti, pada kegiatan pembelajaran masih ada mahasiswa belum memberanikan diri menyimpulkan pembelajaran karena masih ragu-ragu mengutarakan pendapatnya.

3) Tahap See

Pada tahap ini, dosen model dan seluruh observer berkumpul dalam satu ruangan membahas apa yang telah terjadi pada saat pelaksanaan proses pembelajaran. Dari hasil diskusi dan pemaparan hasil observasi dapat disimpulkan bahwa pelaksanaan Lesson Study I belum maksimal

b. Pelaksanaan Lesson Study II

1) Tahap Plan

Pada tahap ini, guru/dosen secara bersama-sama melakukan analisis silabus untuk membuat lesson design. Kegiatan lesson design ini dilakukan untuk merancang kegiatan yang akan dilaksanakan pada saat proses pembelajaran. Dengan adanya kekurangan yang terjadi pada pelaksanaan Lesson Study I, maka pada tahap ini dilkukan beberapa penyempurnaan diantaranya melaksanakan perbaikan tindakan Lesson Study II. Dosen model dan observer menyiapkan lesson design dan lembar kerja yang akan dibagikan ke mahasiswak.

2) Tahap Do

Melalui perbaikan dalam pembelajaran Lesson Study II ini diharapkan dapat meningkatkan membelajaran dengan menggunakan metode tutor sebaya (reciprokal teaching) dan diikuti pula dengan adanya perubahan perilaku mahasiswa. Mahasiswa diharapkan menjadi lebih aktif dan lebih antusias 
dalam mengikuti matakuliah dan kegiatan diskusi.

Pada Lesson Study II, yaitu pada kegiatan mahasiswa membentuk kelompok menunjukkan bahwa pada kegiatan pembelajaran didominasikan oleh mahasiswa yang aktif sebanyak 22 mahasiswa (88\%), mahasiswa yang tidak aktif sebanyak 3 atau $(12 \%)$. Dari hasil pengamatan semua mahasiswa aktif pada saat membentuk kelompok karena adanya pengarahan dan pemahamn dari guru pentingnya bekerja dalam sebuah tim.

Pada kegiatan berdiskusi dalam kelompoknya menunjukkan adanya 21 mahasiswa (84\%) yang aktif, dan 4 atau (19\%) mahasiswa yang tidak aktif. Pada saat diskusi kelompok berlangsung, guru memantau proses diskusi kelompok denagn berkeliling dalam ruangan kelas, guru mengarahkan mahasiswa untuk tidak melakukan aktivitas lain dan member pemahaman pentingnya bekerjasama dalam sebuah kelompok. Menurut pengamatan peneliti, semua mahasiswa aktif pada saat proses pembelajaran.

Diskusi kelas kembali dilanjutkan setelah diskusi kelompok berlangsung. Semua kelompok bersemangat memaparkan hasil diskusinya. Setelah proses pembelajaran berlangsung, Mahasiswa mengumpulkan hasil diskusinya kemudian menunjuk perwakilan untuk memaparkan hasil diskusinya dan kelompok yang lain memberikan tanggapan. Terlihat mahasiswa sudah menunjukkan keaktifannya dalam diskusi ketika mempertahankan pendapatnya dan menyanggah pendapat lain. Hal ini menjadikan proses pembelajaran berlangsung dengan aman. Guru juga telah menunjukkan kemampuan dan mengarahkan jalannya diskusi dengan baik. Pada kegiatn menanggapi dan memaparkan hasil diskusi kelas diperoleh data sebayak 21 mahasiswa atau $(84 \%)$ yang aktif dan yang tidak aktif 4 mahasiswa atau (19\%), sedangkan menanggapi hasil diskusi sebayak $17 \quad(68 \%)$ mahasiswa yang aktif , mahasiswa yang tidak aktif sebayak 8 (32\%). Menurut pengamatan peneliti, pada kegiatan pembelajaran ini sudah mengalami peningkatan meskipun pada saat menanggapi diskusi belum semua mahasiswa terlihat antusias.

Pada saat menyimpulkan materi pembelajaran terdapat 13 (52\%) yang aktif dan yang tidak aktif 12 (48\%) mahasiswa. Menurut pengamatan peneliti, pada kegiatan pembelajaran ini sudah berjalan maksimal

3) Tahap See

Pada lesson study II ditemukan beberapa kelebihan-kelebihan penerapan lesson study di antaranya: (1) siswa lebih berkembang keterampilan inkuiri (inquiry skill),

Aktivitas pembelajaran siswa meningkat sehingga siswa lebih senang dalam belajar, (3) siswa lebih berkesempatan untuk mencari informasi yang lebih luas, (4) melalui presentasi hasil riset, siswa lebih 
mengembangkan kemampuan komunikasi dan menambah rasa percaya diri, (5) memberikan kesempatan kepada siswa untuk mengaplikasikan pengetahuan yang mereka miliki dalam dunia nyata,

\section{Pembahasan Hasil Penelitian}

a. Pelaksanaan Lesson Study I

1) Pertemuan Pertama

Pada tahap pelaksanaan tindakan, aktivitas mahasiswa pada lesson study I menunjukkan bahwa pada kegiatan awal pembelajaran, mulai pada kegiatan menyimak tujuan pembelajaran, dan menyimak informasi materi pembelajaran mahasiswa tampak aktif. Akan tetapi, pada kegiatan pengenalan materi pembelajaran mahasiswa tampak kurang aktif mengemukakan pendapatnya. Pada penerapan metode pembelajaran tutor sebaya (reciprokal teaching) dalam pembelajaran dimulai dari menyampaikan tujuan pembelajaran yang ingin dicapai, memberikan materi pembelajaran, berdasarkan hasil pengamatan pada proses kegiatan pembelajaran berlangsung, menunjukkan penelitian tindakan pada lesson study I belum berhasil secara maksimal.

b. Pelaksanaan Lesson study II

Pada lesson study II pertemuan pertama aktivitas mahasiswa tampak mengalami perubahan. Secara umum, lesson study II lebih baik daripada lesson study I, pada lesson study ini lebih banyak mahasiswa yang aktif, karena kendala-kendala yang terjadi pada lesson study I telah diperbaiki pada pembelajaran lesson study II. Semua aktivitas guru dan mahasiswa dalam proses pembelajaran telah terlaksana dengan baik. Aktivitas mahasiswa yang antusias dalam pembelajaran menunjukkan bahwa metode ini terbukti mampu mengaktifkan mahasiswa dalam pembelajaran. Selain itu, pemberian motivasi yang dilakukan guru terhadap mahasiswa dalam pembelajaran terbukti dapat menumbuhkan rasa percaya diri mahasiswa sehingga semua tujuan pembelajaran yang pelaksanaannya belum tuntas pada lesson study I, dapat mencapai ketuntasan pada pembelajaran lesson study II.

Pelaksanaan lesson study II tersebut memberikan petunjuk kepada kita semua kelebihan metode tutor sebaya yang dikemukakan oleh Trianto (2002:173-174) dapat meminimalisir kesenjangan yang terjadi antara mahasiswa yang prestasinya rendah dengan mahasiswa yang prestasinya lebih tinggi dalam suatu kelas. Selanjutnya mahasiswa termotivasi dalam menyelesaikan tugas dan motivasi itu diharapkan tumbuh dari terciptanya hubungan yang saling menguntungkan dan membutuhkan antara guru, mahasiswa

\section{KESIMPULAN}

Berdasarkan rumusan masalah, hasil penelitian, dan pembahasan dalam penelitian ini, maka dapat disimpulkan hal-hal berikut ini.

a. Proses pembelajaran pada lesson study II sudah lebih baik setelah dilakukan perbaikan terhadap masalah pada lesson study I. Pada lesson study II, suasana kelas dalam proses pembelajaran sangat kondusif karena perhatian mahasiswa sudah terfokus pada kegiatan pembelajaran, mahasiswa sudah memahami materi pelajaran 
dan mahasiswa sudah mampu menerapkan metode pembelajaran tutor sebaya (Reciprocal teaching). mahasiswa lebih antusias dan lebih termotivasi dalam pembelajaran dengan menggunakan metode tutor sebaya (Reciprocal teaching) karena mahasiswa tidak hanya sekedar tahu materi yang dipelajarai tetapi juga lebih memahami dan mempertanggungjawabkan hasil belajarnya. Pembelajaran dengan menggunakan metode tutor sebaya juga mengajarkan akan pentingnya kerjasama dan saling berbagi baik itu memberi atau menerima demi tercapainya tujuan yang diinginkan.

b. Adanya peningkatan hasil belajar antara Lesson Study I dan Lesson Study II. Peningkatan itu terlihat dari perubahan nilai rata-rata dari lesson study I ke lesson study II sebesar 69,2 \%. Pada lesson study I, nilai rata-rata yang diperoleh mahasiswa sebesar 84,6 pada lesson study II, hasil yang dicapai mahasiswa sebesar 15,4\%

Berdasarkan hasil pembahasan dan kesimpulan yang telah dikemukakan sebelumnya, diajukan saran berikut ini.

a. Guru senantiasa meningkatkan profesionalismenya dengan kreatif menulis bahan pembelajaran baik berbasis nasional maupun lokal.

Lesson study merupakan akatifitas pembelajaran yang sangat baik untuk mendongkrak kemampuan seorang dosen dalam menjalankan tugas tri dharma perguruan tingginya, oleh karena itu diperlukan usaha yang berkesinambungan agar pelaksanaan Lesso Study ini tidak hanya berhenti pada tingkat progdi saja, akan bisa lebih luas jangkauannya

\section{REFERENSI}

Arikunto, Suharsimi., Suharjono, \& Supardi. 2010. Penelitian Tindakan Kelas. Jakarta: Bumi Aksara.

Basrowi, Muhammad dan Suwandi. 2008. Prosedur Penelitian Tindakan Kelas. Bogor: Ghalia Indonesia

Depdiknas. 2005. Kamus Besar Bahasa Indonesi. Jakarta: Pusat Bahasa Departemen Pendidikan Nasional.

Haling, Abdul. 2006. Belajar dan Pembelajaran. Makassar: Badan Penerbit UNM.

Lie anita. 2008.Pembelajaran dengan Metode Tutor Sebaya. Jakarta. Grasindo.

Sahabuddin. 2007. Mengajar dan belajar: Dua Aspek dari Suatu Proses yang Disebut Pendidikan.Diktat. Makassar: FBS UNM.

Santyasa WI. 2009. Implementasi Lesson study Dalam Pembelajaran. Makalah dalam "Seminar Implementasi Lesson Study dalam Pembelajaran bagi Guru-Guru TK, Sekolah Dasar dan Sekolah Menengah Pertama di Kecamatan Nusa Penida, 24 Januari 2009, Nusa Penida.

Trianto. 2010. Mendesain Model Pembelajaran Inovatif-Progresif: Konsep Landasan dan Implementasinya Pada Kurikulum Tingkat Satuan Pendidikan (KTSP). Jakarta: Kencana Prenada Media Group.

Wiludjeng, Insih. 200. Reciprocal Teaching Sebagai Upaya Melatih Kemandirian Siswa dalam Proses 
Belajar. Yogyakarta. Jurdik Fisika FPM IPA UNY

Yusak, Muchlak. 2008. Lesson Study. Jakarta. 